\title{
The Cause for Water-Heart Fruit of Pineapple and Protective Measurements
}

\author{
Haiyan Shu, Wei Sun, Keming Li, Guiying Xu, Rulin Zhan*, Shenghe Chang* \\ Haikou Experimental Station, Chinese Academy of Tropical Agricultural Sciences, Haikou, China \\ Email: *plantfood772@hotmail.com
}

How to cite this paper: Shu, H.Y., Sun, W., Li, K.M., Xu, G.Y., Zhan, R.L. and Chang, S.H. (2019) The Cause for Water-Heart Fruit of Pineapple and Protective Measurements. American Journal of Plant Sciences, 10, 885-892.

https://doi.org/10.4236/ajps.2019.106063

Received: April 17, 2019

Accepted: May 31, 2019

Published: June 3, 2019

Copyright $\odot 2019$ by author(s) and Scientific Research Publishing Inc. This work is licensed under the Creative Commons Attribution-NonCommercial International License (CC BY-NC 4.0).

http://creativecommons.org/licenses/by-nc/4.0/ (c) (i) (9) Open Access

\begin{abstract}
Pineapple industry has played important roles in China's economics in tropical- and subtropical-areas. Pineapple industry in China has been damaged by water-heart fruit. The objective of this research is to clarify the mechanism underlying water-heart fruit of pineapple and find ways for preventing water-heart fruit. We found that water logging can cause water-heart pineapple. The longer the pineapple plants were water logged, the more fruits were found water heart. With the development of fruits, the fruits' sensitivity to water logging increased. Spraying potassium sulfate onto the fruits after the plants are water logged can decrease the rate of pineapple water-heart. But this effect became less with the fruit development. When sucrose and its precursors in intracellular space were transferred into sink cells, hydrogen ions were required. Because of lacking hydrogen ions, sucrose and its precursors were stopped in intracellular space and seized water from cells. Water-heart fruit formed. If potassium can be gotten in intracellular space, the roles of hydrogen ions might be replaced with potassium ions. With the help of potassium ions, sucrose and its precursors were transported into sink cells and the water-heart symptoms alleviated.
\end{abstract}

\section{Keywords}

Water-Heart Fruit, Pineapple, Water Logging, Potassium, Hydrogen Ions

\section{Introduction}

Pineapple is the third largest tropical fruit in production in China. In 2013, pineapple planting area in China was the fourth largest in the world. Pineapple yield in China was the eighth largest in the world. Pineapple industry played important roles in tropical economics in China. Pineapple in China is mainly cultivated in Guangdong, Hainan, Yunan, Guangxi, Fujian, Taiwan. Eigh${ }^{\star}$ Corresponding author. 
ty-four percent of pineapple production was from Guangdong and Hainan [1]. The main variety of pineapple in China is "Comte de Paris" [2]. The pineapple fruits are mainly sold in fresh fruits. The fruits are mainly sold in home market [1].

In recent years, water-heart fruits have been found in market. After being cut, water damage can be found on the section plane. The difference between the water-heart fruit and the normal fruit cannot be found from the surface. If dealers buy water-heart fruits, their interests will be lost. They will not buy pineapple fruits in the same area in the next year. The price of pineapple will fall. Water-heart fruit is a hidden danger for pineapple industry.

What caused water-heart pineapple? How to prevent water-heart fruit? Resolving these problems will be important for Chinese pineapple industry. These problems are studied in this research.

\section{Materials and Methods}

The test plot localized at Dachang village, Wenchang, Hainan province, China. The climate is tropical monsoon and ocean climate. The quantity rainfall in a year is $1279.10 \mathrm{~mm}$. the evaporation quantity in a year is two times of the rainfall. The soil is red soil. The average temperature of soil is $24^{\circ} \mathrm{C}-25^{\circ} \mathrm{C}$. The volume weight of the soil is $1.32 \mathrm{~g} / \mathrm{cm}^{3}$. Ph is 5.1. the organic matter content is 8.56 $\mathrm{g} / \mathrm{kg}$. The content of nitrogen, phosphate, potassium, calcium, magnesium is $83.24 \mathrm{mg} / \mathrm{kg}, 121.33 \mathrm{mg} / \mathrm{kg}, 171.72 \mathrm{mg} / \mathrm{kg}, 262.48 \mathrm{mg} / \mathrm{kg}, 56.59 \mathrm{mg} / \mathrm{kg}$, respectively. The test variety is "Comte de Paris" [Ananascomosus (Linn.) Merr. cv. "Comte de Paris"] [3].

The pineapple seedlings were planted on December 10, 2017. The inflorescence was forced on December 10, 2018. The fruits were harvested on April 10, 2019. The first water-logging treatment (SBH) was done on February 10, 2019. The plants were treated for 1 day, 3 days, and 7 days, respectively. The ground was covered and kept with water for $1 \mathrm{~cm}$. The second water-logging treatment (TBH) was done on March 10, 2019. The plants were treated for 1 day, 3 days, and 7 days, respectively. The ground was covered and kept with water for $1 \mathrm{~cm}$. The third water-logging treatment (WBH) was done on March 20, 2019. The plants were treated for 1 day, 3 days, and 7 days, respectively. The ground was covered and kept with water for $1 \mathrm{~cm}$. The area of each plot was $2.70 \mathrm{~m} \times 10 \mathrm{~m}$ and randomly arranged. Except the control, each plot was replicated 6 times. After being water logged, three replicates of them were sprayed with $2.5 \%$ potassium sulfate. Five liter potassium sulfate solution was sprayed for each plot. The daily management of the test plot was the same with that of farms. The quantity of nitrogen, phosphate, potassium, magnesium used in the whole growing stage was $\mathrm{N} 772.95 \mathrm{~kg} \cdot \mathrm{hm}^{-2}, \mathrm{P}_{2} \mathrm{O}_{5} 497.26 \mathrm{~kg} \cdot \mathrm{hm}^{-2}, \mathrm{~K}_{2} \mathrm{O} 972.5 \mathrm{~kg} \cdot \mathrm{hm}^{-2}, \mathrm{MgO} 75$ $\mathrm{kg} \cdot \mathrm{hm}^{-2}$, respectively. The plants were watered normally one time every 10 days. On April 10, 2019, the fruits were harvested and cut. The water-heart fruits were investigated and calculated. 


\section{Results}

\subsection{The Effects of Water-Logging Duration Time on Water-Heart Rate}

Since water heart in pineapple always appeared in summer, when heavy rains often arrived. And so, we speculated that water might cause water-heart fruit in pineapple. Water loggings were designed for identifying this hypothesis. Pineapple plants were water logged for 1 day, 3 days, and 7 days, respectively. Results showed that water logging has close relationship with water-heart fruit. The longer the plants were water logged, the more water-heart fruits were found. In the treatment TBH, 7\% of fruits were found water heart if the plants were treated for one day. This rate was $15 \%$ if the plants were treated for three days. If the plants were water logged for 7 days, this rate reached to $51 \%$ (Figure 1). In treatments of $\mathrm{SBH}$ and $\mathrm{WBH}$, similar results had also been found (Figure 1). The longer the pineapple plants were water logged, the more fruits were found water heart.

\subsection{The Relationship between Water-Heart Rate of Fruits and Treating Stage}

To check whether the developing stage of fruits can affect the water-heart rate of fruits, the pineapple plants were water logged from the day that 60 days before harvest, 30 days before harvest, and 20 days before harvest, respectively. Results showed that if the treating duration time was the same, the fruits those 20 days before harvest had the most water-heart rate. For example, in the plants that were water logged for 3 days, if the plants were treated 60 days before harvest, the water-heart rate was 9\%. If the plants were water logged 30 days before harvest, the water-heart rate was $15 \%$ (Figure 2). If the plants were treated 20 days before harvest, this rate increased to $20 \%$. In the fruits those were treated for 1 day and 7 days, similar results were also found (Figure 3 and Figure 4). These indicated that with the development of fruits, the fruits' sensitivity to water logging increased.

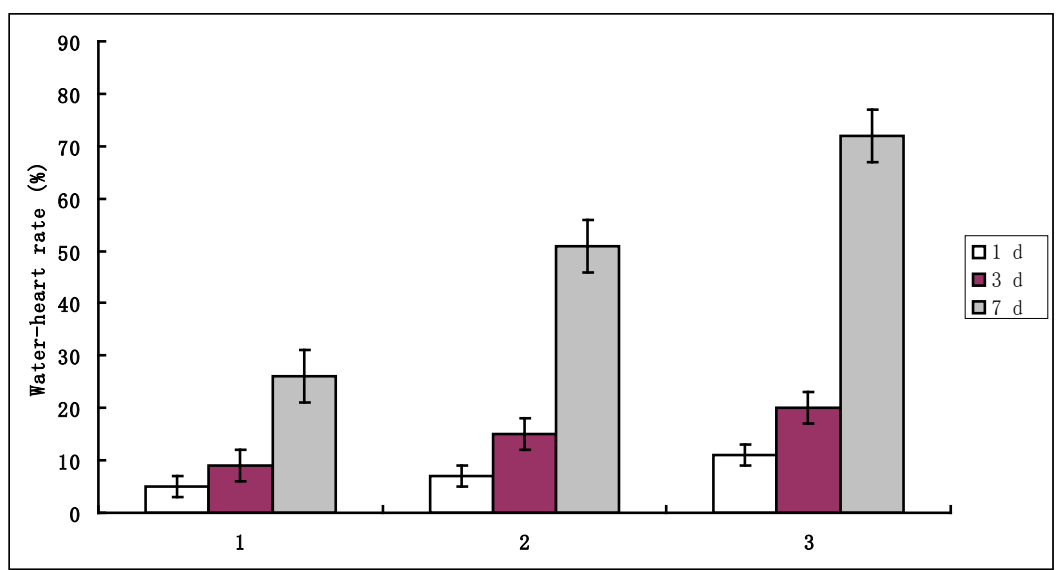

Figure 1. Water-heart rates of pineapple fruits. 1, 2 and 3 represented the treatments of $\mathrm{SBH}, \mathrm{TBH}$, and $\mathrm{WBH}$, respectively. The $\mathrm{p}$ value was less than 0.01 . 


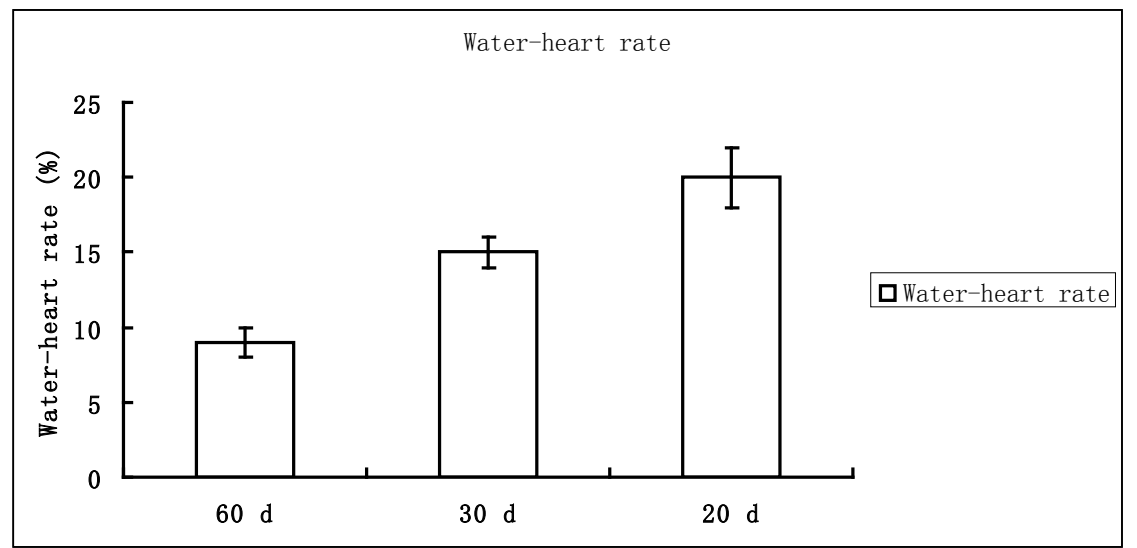

Figure 2. Water-heart rate of pineapple fruits those plants were water logged for 3 days. The $\mathrm{p}$ value was less than 0.01 .

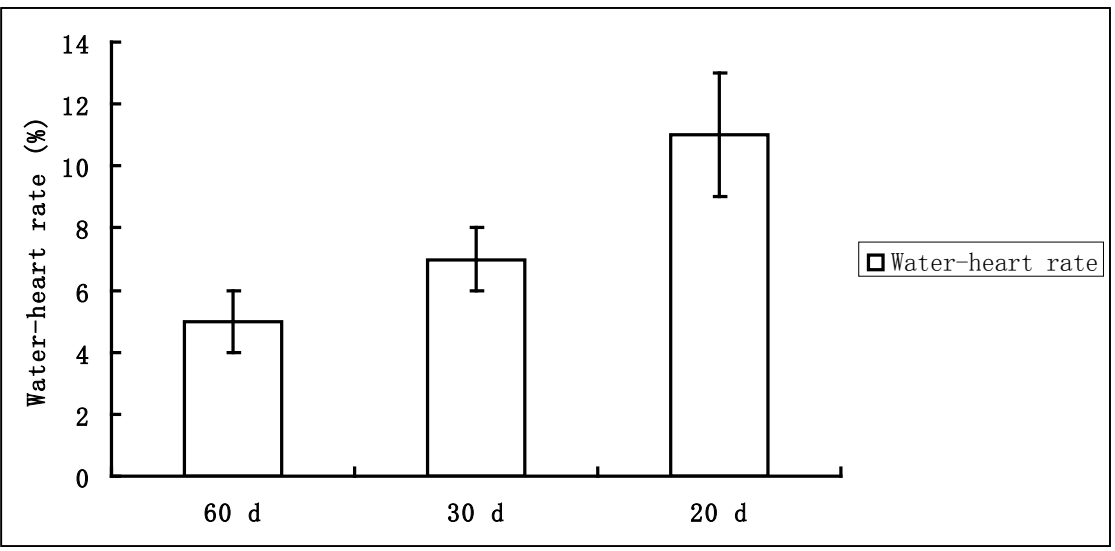

Figure 3. Water-heart rate of pineapple fruits those plants were water logged for 1 day. The $\mathrm{p}$ value was less than 0.01 .

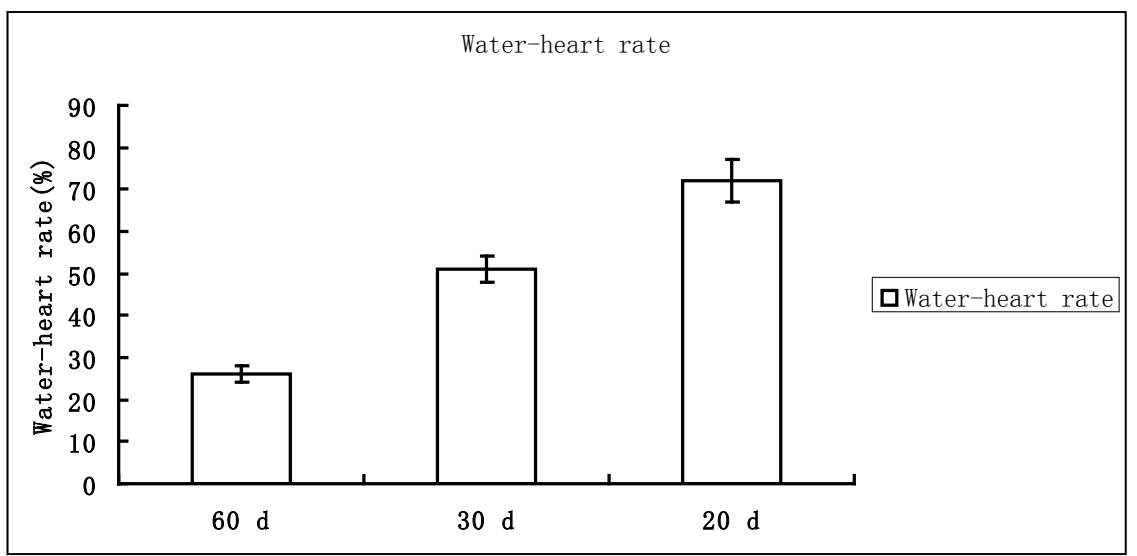

Figure 4. Water-heart rate of pineapple fruits those plants were water logged for 7 days. The $\mathrm{p}$ value was less than 0.01 .

\subsection{Spraying Potassium Solution onto the Fruits Can Prevent Water Heart}

Since some people reported that in the condition those plants were water logged, 
the potassium content in the above-ground tissues decreased remarkably, we speculated that spraying potassium might be able to alleviate the injury of water heart. Therefore, after be logged, pineapple fruits on some plants were sprayed with $2.5 \%$ potassium sulfate. Results showed that on the same conditions, water-heart rates of fruits sprayed with potassium sulfate were significantly than those sprayed with water. In the fruits those plants were water logged 60 days before harvest, no water-heart fruit had been found in the fruits sprayed with potassium sulfate (data not shown). In the fruits those plants were water logged 30 days before harvest, in the plants those were water logged for 1 day, no water-heart fruits had been found in the fruits sprayed with potassium sulfate. In the plants those were water logged with 3 days, $2 \%$ of the fruits sprayed with potassium sulfate were found water heart. In the plants those were water logged for 7 days, $5 \%$ of the fruits sprayed with potassium sulfate were found water heart (Figure 5). Similar results were also found in fruits those plants were water logged 20 days before harvest (Figure 6). These results demonstrated that spraying potassium sulfate onto the fruits after the plants were water logged can decrease the rate of pineapple water-heart. But this effect became less with the fruit development.

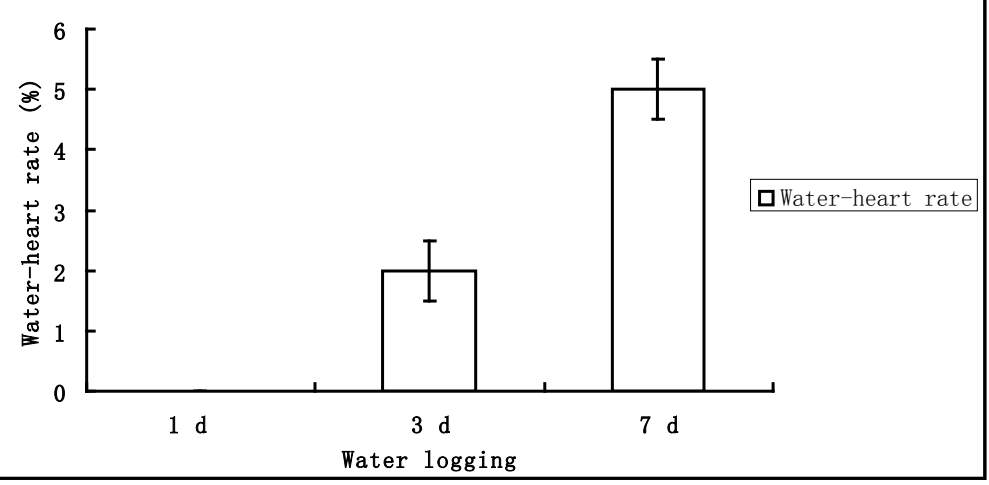

Figure 5. Water-heart rate of pineapple treated with water logging 30 days before harvest and sprayed with potassium sulfate. The $\mathrm{p}$ value was less than 0.01 .

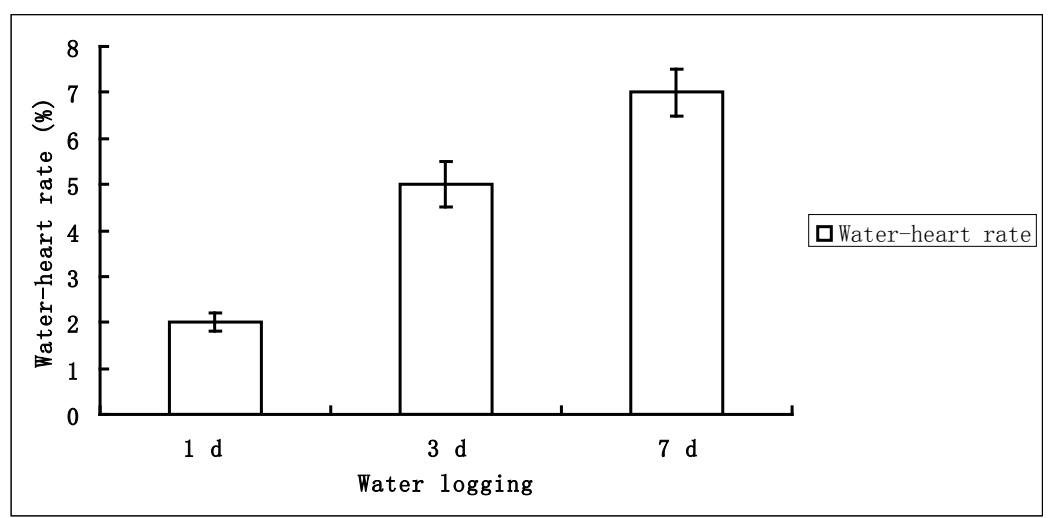

Figure 6. Water-heart rate of pineapple treated with water logging 20 days before harvest and sprayed with potassium sulfate. The $\mathrm{p}$ value was less than 0.01 . 


\section{Discussion}

Water-heart in pineapple can be induced by water logging, indicating that water logging had the close relationship with water-heart of pineapple. When plants were water logged, oxygen around roots was deficient. Aerobic respiration was not enough. Anaerobic respiration increased. The synthesis of ATP reduced [4] [5]. At the same time, the content of 1-aminocyclopropane-1-carboxylate (ACC), the precursor of ethylene, in roots increased when roots were water logged [6]. When ACC was transported into the above-ground tissues, it reacted with oxygen and transformed into ethylene. This caused that the ethylene in the above-ground tissues increased. The fruit matures faster. When roots of plant were water logged, the quantity of photosynthesis decreased [7] [8]. The products of photosynthesis were transferred into sink cells in the fruits through symplast or apoplast [9] [10] [11] [12]. The products of photosynthesis transferred through symplast can enter the sink cells directly. But the products of photosynthesis transferred through apoplast will reach the intracellular space first. And then, they were transferred into sink cells [13]. The main product of photosynthesis in pineapple was sucrose. When sucrose was transferred into cell, it needed hydrogen ions transferred together [14] [15] [16] [17]. However, because of lacking ATP, no enough hydrogen ions can be pumped out from intra cell. There were not enough hydrogen ions in the intracellular space. Sucrose was stopped in intracellular space. Sucrose itself is an osmotic substance. It can capture water from intra cell. Water flowed out of cells and into intracellular space. Much water was kept in intracellular space. On the other hand, because fruit matures faster, much precursors of sucrose are also transferred into intracellular space. ATP was required if they were transformed into sucrose. Because of lacking ATP, these precursors were also kept in intracellular space and captured water from intra cell. Much water accumulated in intracellular space, and then, water-heart fruit formed. At the early stage of fruit development, photosynthesis products were mainly transferred through symplast. With the fruit development, photosynthesis products transferred through apoplast increased and photosynthesis products transferred through symplast decreased [16]. Therefore, more water-heart fruits were found in the plants treated with water logging 30 days before harvest than those treated with water logging 60 days before harvest. Less water-heart fruits can be found in fruits treated at the early stage.

Steffens et al. [4] reported that potassium in above-ground tissues of plants treated with water logging was significantly less than that of control. This finding urged us to speculate that if potassium was sprayed onto the fruits of pineapple treated with water logging, water-heart symptoms of pineapple might be alleviated. Our experiments demonstrated that spraying potassium sulfate onto pineapple fruits after the plants were water logged, the symptoms of water heart in pineapple fruits did ease. Furthermore, the effect of spraying potassium sulfate onto early-stage fruits was better than those of late stage fruits. However, the mechanisms underlying this phenomenon have not been reported. When su- 
crose and its precursors in intracellular space were transferred into sink cells, hydrogen ions were required. Just because of lacking hydrogen ions, water-heart fruit formed. If potassium can be gotten in intracellular space, the roles of hydrogen ions might be replaced with potassium ions. With the help of potassium ions, sucrose and its precursors were transported into sink cells and the water-heart symptoms alleviate.

\section{Acknowledgements}

This work was supported by Central Public-interest Scientific Institution Basal Research Fund for Chinese Academy of Tropical Agricultural Sciences (No. 1630092019005).

\section{Conflicts of Interest}

The authors declare no conflicts of interest regarding the publication of this paper.

\section{References}

[1] Jin, Y. (2016) The Pineapple Industry of China Development Report and Situation Forecast in 2015. Information in Tropical Agriculture in World, 9, 16-24.

[2] Li, Y., Wu, Y., Wu, B., Zou, M., Zhang, Z. and Sun, G. (2011) Exogenous Gibberellic Acid Increases the Fruit Weight of "Comte de Paris" Pineapple by Enlarging Flesh Cells without Negative Effects on Fruit Quality. Acta Physiologiae Plantarum, 33, 1715-1722. https://doi.org/10.1007/s11738-010-0708-2

[3] He, J.H., Chen, H.R., Huang, H.J., Wang, J.H. and Huang, H.N. (2015) The New Varieties and High-Quality- and High-Production-Cultivation Technology of Pineapple (Ananas comosus L.). China Agricultural Science and Technology Press, Beijing.

[4] Steffens, D., Hütsch, B.W., Eschholz, T., Lošák, T. and Schubert, S. (2005) Water Logging May Inhibit Plant Growth Primarily by Nutrient Deficiency Rather than Nutrient Toxicity. Plant, Soil and Environment, 51, 545-552. https://doi.org/10.17221/3630-PSE

[5] Drew, M.C. (1988) Effects of Flooding and Oxygen Deficiency on Plant Mineral Nutrition. Advances in Plant Nutrition, 3, 115-159.

[6] Metraux, J.P. and Kende, H. (1983) The Role of Ethylene in Growth Response of Submerged Deep Water Rice. Plant Physiology, 72, 441-446.

https://doi.org/10.1104/pp.72.2.441

[7] Zhang, Y., Kong, X., Dai, J., Luo, Z., Li, Z., Lu, H., Xu, S., Tang, W., Zhang, D., Li, W., Xin, C. and Dong, H. (2017) Global Gene Expression in Cotton (Gossypium hirsutum L.) Leaves to Waterlogging Stress. PLoS ONE, 12, e0185075. https://doi.org/10.1371/journal.pone.0185075

[8] Zhang, Y., Song, X., Yang, G., Li, Z., Lu, H. and Kong, X. (2015) Physiological and Molecular Adjustment of Cotton to Waterlogging at Peak-Flowering in Relation to Growth and Yield. Field Crops Research, 179, 164-172. https://doi.org/10.1016/j.fcr.2015.05.001

[9] Reinders, A., Schulze, W., Kühn, C., Barker, L., Schulz, A., Ward, J.M. and Frommer, W.B. (2002) Protein-Protein Interactions between Sucrose Transporters of 
Different Affinities Colocalized in the Same Enucleate Sieve Element. Plant Cell, 14, 1567-1577. https://doi.org/10.1105/tpc.002428

[10] Barth, I., Meyer, S. and Sauer, N. (2003) Pm SUC3: Characterization of a SUT2/SUC3-Type Sucrose Transporter from Plantago Major. Plant Cell, 15, 1375-1385. https://doi.org/10.1105/tpc.010967

[11] Aoki, N., Scofield, G.N., Wang, X.D., Patrick, J.W., Offler, C.E. and Furbank, R.T. (2004) Expression and Localization Analysis of the Wheat Sucrose Transporter Ta SUT1 in Vegetative Tissues. Planta, 219, 176-184. https://doi.org/10.1007/s00425-004-1232-7

[12] Gahrtz, M., Stolz, J. and Sauer, N. (1994) A Phloem-Specific Sucrose-H+ Symporter from Plantago Major L. Supports the Model of Apoplastic Phloem Loading. The Plant Journal, 6, 697-706. https://doi.org/10.1046/j.1365-313X.1994.6050697.x

[13] Lalonde, S., Tegeder, M., Throne-Holst, M., Frommer, W.B. and Patrick, J.W. (2003) Phloem Loading and Unloading of Sugars and Amino Acids. Plant Cell and Environment, 26, 37-56. https://doi.org/10.1046/j.1365-3040.2003.00847.x

[14] Ward, J.M., Kühn, C., Tegeder, M. and Frommer, W.B. (1998) Sucrose Transport in Higher Plants. International Review of Cytology, 178, 41-71.

https://doi.org/10.1016/S0074-7696(08)62135-X

[15] Lemoine, R. (2000) Sucrose Transporters in Plants: Update on Function and Structure. Biochimica et Biophysica Acta BBA-Biomembranes, 1465, 246-262. https://doi.org/10.1016/S0005-2736(00)00142-5

[16] Riesmeier, J.W., Hirner, B. and Frommer, W.B. (1993) Expression of the Sucrose Transporter from Potato Correlates with the Sink-to-Source Transition in Leaves. The Plant Cell, 5, 1591-1598. https://doi.org/10.2307/3869741

[17] Weise, A., Barker, L., Kühn, C., Lalonde, S., Buschmann, H., Frommer, W.B. and Ward, J. (2000) A New Subfamily of Sucrose Transporters, SUT4, with Low Affinity/High Capacity Is Localized in Enucleate Sieve Elements of Plants. Plant Cell, 12, 1345-1355. https://doi.org/10.1105/tpc.12.8.1345 